\title{
UNSUR KOMBINASI PADA VISUALISASI RAGAM HIAS BATIK KLASIK SEMÈN GAYA YOGYAKARTA
}

\author{
Suryo Tri Widodo, G.R. Lono Lastoro Simatupang, \\ R.M. Soedarsono, dan SP. Gustami
}

\begin{abstract}
Semèn motifs on classical batik of Yogyakarta style, is a motif which visualize floral form with various elements motifs on it. Semèn motifs influenced Hindu-Java and Islamic culture. Influence from Islamic culture delivere a few motifs in stylization. From visual aspect, some of elements motifs on it visualize combine motifs. It become visual concept characteristic in Islam art include in semèn motifs on classical batik of Yogyakarta style. Visualization of motifs can be hide with combined elements motifs.
\end{abstract}

Keywords: semèn motifs, Yogyakarta classical batik, combine motifs

\section{PENDAHULUAN}

Artikel ini merupakan kajian lanjutan yang penulis lakukan pada penelitian sebelumnya dengan judul 'Visualisasi Ragam Hias Batik Klasik Semèn Gaya Yogyakarta' (2014). Seperti uraian pada penelitian terdahulu, bahwa ragam hias semèn merupakan ragam hias batik yang menggambarkan unsur utama berupa tetumbuhan dengan berbagai unsur ragam hias lain yang bersifat majemuk. Secara visual ragam hias semèn sangatlah menarik dan dinamis, karena di dalamnya tidak hanya memuat satu unsur ragam hias semata, namun juga memuat berbagai macam unsur dan jenis ragam hias yang dirangkai dan disusun menjadi satu dalam sebuah perwujudan kain batik secara utuh (Widodo, 2014).
Ragam hias semèn memiliki banyak variasi maupun turunannya dengan berbagai nama. Ragam hias ini memang sangat memungkinkan untuk diubah atau digubah sesuai dengan selera pembuatnya, baik dari aspek visualisasinya maupun unsur-unsur ragam hias di dalamnya, sehingga ia menjadi sebuah jenis ragam hias yang berkembang secara dinamis disesuaikan dengan fungsinya. Demikian pula dari aspek visualisasinya, yang setelah dilakukan pengamatan dan kajian lebih lanjut, maka terdapat beberapa ragam hias yang diwujudkan dari beberapa unsur kombinasi ragam hias yang lain. Hal ini menjadi sesuatu yang menarik untuk diungkap dan ditelaah secara lebih lanjut.

Terkait dengan permasalahan di atas, maka artikel ini secara khusus menyoroti aspek visual pada ragam hias

*) Suryo Tri Widodo (suryotw@gmail.com.) Staf Pengajar Program studi Kriya Seni, Jurusan Kriya, Fakultas Seni Rupa, Institut Seni Indonesia Yogyakarta; G.R. Lono Lastoro Simatupang, R.M. Soedarsono, dan SP. Gustami, Staf Pengajar Prodi Pengkajian Seni Rupa dan Seni Pertunjukan, Fakultas Ilmu Budaya, Universitas Gadjah Mada Yogyakarta. 
semèn rama, semèn sida mukti, dan semèn sida luhur gaya Yogyakarta. Fokus kajian adalah pada perwujudan beberapa unsur ragam hias utama yang di dalam perwujudannya merupakan gabungan atau kombinasi dari unsur ragam hias lain. Pada hasil dan pembahasan akan diuraikan mengenai konsep visual dari ragam hias semèn gaya Yogyakarta, sebagai bahasan pertama. Pembahasan kedua mengenai unsur kombinasi pada ragam hias yang diterapkan sebagai kajian utama dalam tulisan ini. Artikel ini diakhiri dengan simpulan sebagai penutup sekaligus simpulan-simpulan pemahaman dari pembahasan sebelumnya.

\section{Metode}

Penelitian ini menggunakan cara penelitian kualitatif sebagai rangkaian proses menjaring informasi dari kondisi sewajarnya dalam kehidupan suatu objek yang dihubungkan dengan pemecahan suatu masalah, baik dari sudut pandang teoretis maupun praktis. Lazimnya penelitian kualitatif, maka data yang dikumpulkan bersifat deskriptif, berbentuk uraian kalimat sebagai informasi mengenai keadaan sebagaimana adanya sumber data dalam hubungannya dengan masalah yang diselidiki (Nawawi, 1995: 209-211).

Untuk mendapatkan data penelitian yang lengkap dan akurat sesuai dengan yang dibutuhkan, sudah barang tentu diperlukan sebuah metode pengumpulan data yang tepat sesuai dengan tujuan penelitian. Metode pengumpulan data ditempuh melalui beberapa tahapan sebagai berikut. 1) Studi kepustakaan dengan metode pengumpulan data dokumentasi, dilakukan guna menjaring data berupa sumber tertulis dan data visual. Data ini diperoleh dari bukubuku terbitan, jurnal ilmiah, makalah ilmiah, literatur, majalah, surat kabar, manuskrip, dan lain sebagainya. Materi yang dikumpulkan adalah yang relevan serta disesuaikan dengan topik penelitian; 2) Studi lapangan dengan metode observasi dan wawancara. Observasi dilakukan dengan cara pengamatan dan pemotretan secara langsung pada artefak berupa beberapa kain batik klasik dengan ragam hias semèn gaya Yogyakarta terpilih sebagai objek penelitian. Observasi dilakukan di beberapa lokasi utama yang dipandang representatif, yaitu di Museum Batik Kraton Yogyakarta, Museum Batik Yogyakarta, Museum Ullen Sentalu Yogyakarta, Galeri dan Museum Batik Kuno Danar Hadi Solo, serta di beberapa lokasi atau museum lainnya. Data yang diperoleh berupa data visual, yaitu berupa foto dari objek penelitian. Dengan data ini, maka kajian yang diarahkan secara khusus guna mencermati dan mengidentifikasi rincian struktur dan ciri-ciri visual dari unsur-unsur ragam hias semèn dapat dilaksanakan.

$$
\text { Wawancara dengan model }
$$

instrumen pedoman wawancara, yaitu si pewawancara menetapkan masalah dan pertanyaan yang akan diajukan terhadap beberapa informan kunci yang dipandang mampu, berkompeten, dan berhubungan secara langsung maupun tidak langsung dengan topik penelitian. Informan kunci adalah para ahli yang memahami dan mendalami perihal seni batik, kurator, pengamat batik, pecinta batik, para pembatik, pengusaha batik, serta ahli budaya Jawa yang mampu memberikan data yang relevan. Wawancara diarahkan 
bersifat terbuka, sehingga peneliti dan yang diteliti sama-sama tahu, serta tujuan wawancara juga diberitahukan (Endraswara, 2003: 213). Wawancara dilaksanakan seperti sebuah percakapan bebas namun terarah, sehingga dapat memberikan keleluasaan terhadap para informan kunci agar dapat memberikan informasi yang diketahuinya. Melalui teknik seperti ini, maka diharapkan akan diperoleh data lisan yang luas, mendalam, dan terfokus sesuai dengan permasalahan penelitian. Sebagai penunjang kegiatan pengumpulan data ini dibantu dengan peralatan, yaitu: check list, daftar pertanyaan, alat tulis, kamera foto, alat perekam audio/audio visual, dan lain sebagainya.

Analisis dilaksanakan dengan cara mencermati dan diuraikan satu per satu secara detail dan terperinci, struktur dan ciri-ciri visual dari masing-masing unsur ragam hiasnya dalam perwujudan sebuah pola ragam hias batik secara lengkap. Analisis diarahkan pada aspek komposisi, tata letak, dan elemen-elemen visual yang mewujudkannya, baik unsur garis, bidang, titik atau unsur isian (isèn-isèn), dan warna yang terpadu, sehingga diperoleh suatu bentuk pengertian atau makna tertentu (Suyanto, 2002: 24-25).

\section{Hasil dan Pembahasan}

Keberadaan beberapa hasil kesenian seperti batik klasik yang berkembang di Jawa, tidak terlepas dari masuknya pengaruh Hindu-Buddha dalam perkembangan seni di Indonesia dimulai dengan perkenalan kedua agama tersebut. Unsur-unsur kebudayaan dari India seperti tata susun sosial, cara penulisan, teknologi, termasuk seni, hadir bersamaan dengan penyebaran agama (Sedyawati dalam Soemantri, 2002: 2). Hadirnya agama Islam di Indonesia tersebut juga mempengaruhi tahap perkembangan selanjutnya terhadap eksistensi seni di Indonesia. Penyebaran seni Islam sebagaimana halnya dengan seni Hindu, maka seni Islam di Indonesia pada awalnya juga terpusat di istana penguasa. Penerimaan agama Islam yang berlangsung secara bertahap, tidak terelakkan lagi mengakibatkan pengambilan berbagai bentuk dan gaya seni baru, walaupun pada dasarnya toleransi bentuk-bentuk tua menjadi kunci dari perkembangan seni Islam yang ada di Indonesia (Yudoseputro dalam Soemantri, 2002: 16).

Ragam hias batik dalam wujud yang dikategorikan sebagai pola klasik, sebenarnya sudah lahir sejak zaman kebudayaan Hindu di Indonesia yang terus berkembang dalam masyarakat kebudayaan Islam atau disebut Hindu-Islam. Hal tersebut menimbulkan adanya proses akulturasi dengan kebudayaan nenek moyang yang sudah ada sebelumnya. Penerapan ragam hias di atas kain sebenarnya juga sudah lama dikenal, bahkan sebelum dipergunakan alat yang lazim digunakan dalam pembuatan batik yang disebut dengan canthing (Kawindrasusanto dalam Soedarso, 1998: 116).

Terbentuknya gaya batik di Yogyakarta tentu tidak terlepas dari adanya pengaruh pusat kekuasaan yang terfokus dalam diri seorang raja. Beberapa ragam hias sengaja diciptakan oleh kalangan keraton untuk tujuan politis, dengan maksud agar terjadi keharmonisan kehidupan dalam masyarakat. Hal ini terlihat dengan tidak mudahnya terjadi 
gejolak sosial dalam masyarakat, bahkan sebaliknya akan membawa ketenangan hidup masyarakatnya. Suasana seperti ini diharapkan akan dapat mengkondisikan pengukuhan kedudukan raja dan negara, lengkap dengan kekuasaannya.

Gaya batik pedalaman seperti di Yogyakarta diilhami oleh suasana kejiwaan masyarakat dalam kurun waktu tertentu. Hal ini juga dipengaruhi oleh adanya anggapan bahwa datangnya sumber kekuasaan itu dari kekuatan-kekuatan magis yang dihubungkan dengan kekuatan alam, misalnya awan di langit, bintang di malam hari, matahari bersinar terang, rembulan bercahaya redup, laut kidul bergelombang dahsyat, gunung berapi memuntahkan lahar panas, pusaka-pusaka keramat pembawa kesaktian, kereta kencana yang penuh misteri, kuda-kuda, persenjataan perang, dan lain sebagainya. Materi-materi inilah yang diolah untuk menciptakan gaya batik beraroma magis. Terjadinya proses akulturasi dari berbagai elemen luar, memiliki andil dan ikut mempengaruhi arah gaya batik Yogyakarta kepada titik dasar yang lebih menekankan pada kekuatan daya cipta seni semata. Ini diilhami oleh suasana keramat yang syahdu, yang bertujuan untuk mengangkat derajat gelar kebangsawanan keraton. Suasana demikian dipertahankan guna mendominasi jiwa dan karakteristik gaya batik Yogyakarta, yang nampak memiliki tradisi yang begitu melekat.

Salah satu ciri yang dimiliki oleh batik Yogyakarta pada umumnya memiliki tampilan yang padat, seolah tidak memberi ruang kosong pada lembar desainnya, yang ditempati oleh isen pada tiap titik yang terluang, sebagai cerminan begitu kuatnya ikatan kehidupan sosial masyarakat Yogyakarta dalam satu wadah sosio-kultur yang padu. Pengagungan terhadap pusat kekuasaan seorang raja diartikan sebagai sumber kekuatan magis (Dofa, 1996: 31-33). Masuknya pengaruh agama Islam sedikit banyak juga mengakibatkan perubahan sosial yang terjadi. Orientasi agama Islam yang lebih demokratis memiliki andil dan turut mempengaruhi kreativitas seni batik dalam pengembangan ragam hiasnya (Riyanto, et al., 1997). Pengaruh Islam yang diterima sebagai penuntun hidup yang baru di Jawa melahirkan beberapa ragam hias baru, yaitu kaligrafi dan stilisasi. Stilisasi merupakan penggayaan terhadap ragam hias binatang. Dalam ragam hias baru ini, binatang sebagai motif utama digayakan sebagai ragam hias tumbuhan, sedemikian rupa sehingga seringkali untuk mengidentifikasikannya harus dilakukan pengamatan secara cermat dan teliti (Amin, ed., 2002: 33).

Ragam hias batik khususnya dari jenis semèn sejatinya telah mengalami perkembangan sejak akhir zaman Majapahit, dilanjutkan dengan masa pengaruh kebudayaan Islam, dan akhirnya berkembang sampai sekarang. Dasar ragam hias semèn ini berkembang melalui jalur kerajaan-kerajaan Islam di Jawa seperti Demak-Pajang, Mataram Islam, sampai akhirnya kemudian Surakarta dan Yogyakarta. Melalui jalur ini juga masih dikembangkan ragam hias klasik yang lain, seperti ragam hias ceplok, parang, nitik, dan sida mukti (Susanto, 1984: 25). Pada masa kebudayaan Islam terdapat perpaduan yang harmonis antara rasa dan pikiran, sehingga apabila diperhatikan perkembangan ragam 
hias pada zaman Islam terdapat beberapa gaya dari unsur-unsur ragam hias semèn.

Batik klasik ragam hias semèn tergolong ragam hias kuno yang dikenal di daerah Surakarta dan Yogyakarta sebagai salah satu peninggalan zaman dinasti Mataram Islam di pulau Jawa. Masingmasing dari kerajaan tersebut kemudian menghasilkan batik dengan ciri khas yang berbeda. Ciri khas batik keraton pada umumnya tampak lebih menonjol pada batik Keraton Kasultanan Yogyakarta dengan bentuk pola yang sangat teratur, sebagian besar pola ditata secara geometris, perpaduan warna yang sangat tegas, bahkan terkesan menyolok antara warna coklat dan putihnya, sehingga seringkali memberikan kesan agak kaku (Soerjanto, t.t., 7). Seperti lazimnya karya seni daerah pedalaman, maka ciri khas batik klasik Yogyakarta cenderung memperlihatkan tanda-tanda murung, gelap, dan statis karena dalam perwujudannya bertumpu dan mengutamakan hadirnya keseimbangan yang simetris (Gustami, 2000: 95).

Ragam hias batik klasik semèn gaya Yogyakarta ini dibuat dengan warna biru (wedel), warna coklat-merah (soga), dan putih. Warna ini secara turun-temurun dan secara terus menerus diterapkan pada batik klasik Yogyakarta (Susanto, 1980: 179). Ciri khas batik Yogyakarta yang terletak pada keindahan motif dengan warna utama coklat soga dan biru wedel yang semula lebih banyak menggunakan zat warna alam tersebut, diproses dengan teknik kerokan. Dengan menggunakan keteknikan ini, maka batik Yogyakarta dapat dikembangkan menjadi beratus-ratus motif, yang pada umumnya berlatar putih dengan paduan serasi antara bidang-bidang, garis, dilengkapi dengan isen-isen yang beraneka ragam (Riyanto, et al., 1997: 36).

Meskipun kerajaan Mataram telah terbagi menjadi dua, namun ada beberapa ragam hias yang memiliki kesamaan nama, bentuk, dan makna yang sama. Salah satu di antaranya adalah termasuk ragam hias semèn. Umumnya pewarnaan pada batik klasik gaya Yogyakarta, warna coklat (soga) lebih mengarah ke warna coklat tanah, sedangkan warna putih lebih menekankan pada warna putih asli kain mori. Seringkali warna putih yang diterapkan pada batik klasik gaya Yogyakarta ini menjadi unsur warna yang paling dominan, jika dibandingkan unsur warna lainnya. Adapun pada batik klasik gaya Surakarta, warna coklat (soga) cenderung mengarah kepada warna coklat kekuning-kuningan, sedangkan warna putih mengarah pada warna putih kekuning-kuningan (Suyanto, 2002: 50-51).

1. Ragam Hias Semèn Rama

Unsur-unsur visual dari ragam hias batik klasik semèn rama, terdiri atas delapan ditambah satu yang kemudian disebut sebagai unsur ragam hias pokok. Pada ragam hias semèn rama, unsur-unsur ragam hias pokok dapat dikelompokkan menjadi: (1) ragam hias tumbuhan, yaitu pohon hayat; (2) ragam hias binatang, yaitu garudha, binatang (binatang darat berkaki empat), dan burung; (3) ragam hias benda unsur alam, yaitu mèru dan lidah api; dan (4) ragam hias benda, yaitu pusaka, dhampar, dan baito atau kapal laut. Terdapat dua buah ragam hias semèn rama yang memiliki unsur kombinasi di dalam , yaitu ragam hias garudha dan ragam hias pusaka.

a. Ragam hias garudha 
Unsur ragam hias garudha yang termuat pada batik klasik semèn rama ini, tidak digambarkan dalam bentuk burung garuda yang utuh. Ragam hias garudha diwujudkan dengan sepasang sayap atau lar sebagai sebuah rangkaian ragam hias yang utuh. Ragam hias garudha memiliki tujuh buah susunan atau lapis sayap yang berbentuk meruncing ke atas mengarah ke samping secara berurutan. Lapis pertama dengan dua buah helai bulu sayap, berikutnya berjumlah empat helai, kemudian berikutnya yang terakhir atau yang paling luar berjumlah tujuh buah helai. Visualisasi dari unsur ragam hias garudha ini merupakan kombinasi atau perpaduan antara ragam hias berupa sayap garudha dan ragam hias naga pada bagian kepalanya yang digambarkan dengan mulut yang terbuka.

Ragam hias garudha yang digambarkan sebagai sebuah lar atau satu sayap dengan ujungnya berupa kepala naga, diberi warna biru dan sedikit hitam pada bagian bawah kepala. Ragam hias garudha memiliki unsur warna coklat yang dominan. Bagian bulu berbentuk segitiga dengan warna putih di tengahnya dengan bagian tepi diberi warna hitam. Warna biru diterapkan sebagai bagian pembatas antara lapisan sayap satu dengan lapisan sayap lainnya berjumlah tiga buah, yang diberi isèn-isèn berupa sederet titik-titik atau riningan yang berwarna putih sesuai alur bentuk pembatas sayapnya.

b. Ragam hias pusaka

Ragam hias pusaka digambarkan sebagai sebuah wujud ujung tombak. Bentuk ujung tombak digambarkan berbentuk segitiga melebar seperti sayap burung yang terbuka dan meruncing ke atas.
Pada bagian bawah juga berbentuk segitiga namun lebih kecil dengan sudut meruncing ke bawah. Ragam hias pusaka ini dikombinasikan dengan unsur ragam hias lidah api sebagai ujung tombaknya.

Ragam hias pusaka didominasi oleh warna biru. Pada bagian isèn-isèn berupa titik-titik atau riningan berwarna putih nampak pada bagian tepi bawah yang meruncing. Isen-isen yang nampak pada ragam hias pusaka adalah berupa garisgaris atau sawut berwarna hitam dan juga isen-isen berupa gringsing seperti sisik dengan warna putih di tengahnya. Ragam hias pusaka ini pada bagian puncaknya yang meruncing ke atas dikombinasikan dengan ragam hias lidah api yang cenderung berimbang dalam penerapan warnanya, baik itu penerapan warna biru, warna hitam, maupun warna coklat, dan warna putih sebagai isen-isen yang diterapkan.

2. Ragam Hias Semèn Sida Mukti

Pada ragam hias semèn sida mukti, unsur-unsur ragam hias pokok dapat dikelompokkan menjadi: (1) ragam hias tumbuhan, yaitu pohon hayat; dan (2) ragam hias binatang, yaitu garudha, binatang (binatang darat berkaki empat), dan kerang. Terdapat satu buah ragam hias yang memiliki unsur kombinasi di dalam semèn sida mukti, yaitu ragam hias garudha baik dalam bentuk sawat (dua sayap) maupun lar (satu sayap).

a. Ragam hias garudha

Unsur ragam hias garudha pada ragam hias semèn sida mukti diwujudkan dalam bentuk sawat, yaitu burung garuda dengan dua sayap lengkap dengan bagian ekornya. Pada bagian ekor terdiri atas tujuh buah helai sayap dengan ujung-ujungnya yang lengkung, sedangkan pada sayap 
terdiri dari tiga lapisan sayap. Ragam hias garudha ini diwujudkan dengan dipadukan dengan ragam hias burung dalam wujud dua kepala burung yang masing-masing mengarah ke atas.

Di samping dalam bentuk sawat, ragam hias garudha pada ragam hias semèn sida mukti juga digambarkan dalam bentuk lar atau satu sayap. Jumlah helai bulu sayap keseluruhan duabelas helai, dua helai pada bagian dalam, empat helai pada bagian tengah, dan enam helai pada bagian terluar.

Ragam hias garudha memiliki dua bentuk yang agak berbeda. Pada ragam hias garudha yang digambarkan sebagai sebuah sawat atau dua sayap dengan dua kepala burung pada bagian ujungnya. Secara keseluruhan penerapan warnanya sama persis dengan ragam hias garudha yang digambarkan sebagai sebuah lar. Pada ragam hias garudha yang digambarkan sebagai sebuah lar atau satu sayap yang dikombinasikan dengan ragam hias burung berupa kepala burung yang diberi warna biru dan sedikit hitam pada bagian kepala. Ragam hias garudha memiliki unsur warna coklat yang dominan. Bagian bulu berbentuk segitiga dengan warna putih di tengahnya dengan bagian tepi dengan warna hitam. Warna biru diterapkan sebagai bagian pembatas antara lapisan sayap satu dengan lapisan sayap yang lainnya berjumlah tiga buah, diberi isèn-isèn berupa sederet titik-titik atau riningan yang berwarna putih sesuai alur bentuk pembatas sayap.

\section{Ragam Hias Semèn Sida Luhur}

Pada ragam hias semèn sida luhur, unsur-unsur ragam hias pokok dapat dikelompokkan menjadi: (1) ragam hias tumbuhan, yaitu pohon hayat; (2) ragam hias binatang, yaitu garudha, kijang, dan burung; (3) ragam hias benda unsur alam, yaitu mèru dan lidah api; dan (4) ragam hias benda, yaitu bangunan dan dhampar. Terdapat dua buah ragam hias yang memiliki unsur kombinasi di dalam ragam hias semèn sida luhur, yaitu ragam hias garudha dalam bentuk sawat (dua sayap) dan ragam hias dhampar.

a. Ragam hias garudha

Unsur ragam hias garudha diwujudkan dalam bentuk sawat, yaitu burung garudha lengkap dengan dua buah sayap lengkap dengan ekornya. Perwujudan ragam hias ini dikombinasikan dengan ragam hias kayon atau gunungan pada bagian badan dan ragam hias dhampar pada bagian ekornya. Pada bagian sayap terdiri dari tiga lapisan sayap dengan jumlah helai bulu sayap keseluruhan ada sebelas helai, dengan perincian dua helai pada bagian dalam, tiga helai pada bagian tengah, dan enam helai pada bagian terluar. Bagian ekor terdiri dari empat buah lapisan sayap dengan bagian tengah atau puncaknya meruncing ke bawah berbentuk segitiga.

Ragam hias garudha memiliki unsur warna coklat yang dominan. Bagian bulu berbentuk segitiga dengan warna putih di tengahnya dengan bagian tepi yang berwarna hitam. Warna biru diterapkan sebagai bagian pembatas antara lapisan sayap satu dengan lapisan sayap yang lainnya berjumlah tiga buah, diberi isèn-isèn berupa sederet titik-titik atau riningan yang berwarna putih sesuai alur bentuk pembatas sayap.

b. Ragam hias dhampar

Ragam hias dhampar yang diterapkan pada ragam hias semèn sida 
luhur dikombinasikan dengan ragam hias pohon hayat. Ragam hias dhampar memiliki bentuk dasar berupa belah ketupat atau wajik. Bagian tengah terdapat susunan tiga buah segitiga kecil seperti bintang. Pada bagian atas dan bawah juga terdapat segitiga dengan ukuran yang lebih besar satu mengarah ke atas dan satunya mengarah ke bawah yang masing-masing terdapat ragam hias pohon hayat berupa ukel-ukel seperti sulur-suluran simetris yang mengarah ke atas pada segitiga yang meruncing ke atas dan ke bawah pada segitiga yang meruncing ke bawah. Terdapat dua buah lapisan batu berundak atau pundhen seperti sayap yang terkembang ke arah bawah diberi ragam hias parang. Ragam hias dhampar ini pada bagian puncak seperti mahkota berupa susunan lapisan daun kiri dan kanan masing-masing berjumlah empat buah dengan bagian atas tengah yang mencuat dan meruncing ke atas.

Ragam hias dhampar didominasi oleh warna coklat. Warna hitam diterapkan pada bagian tengah yang berbentuk segi tiga berjumlah lima buah. Warna biru diterapkan sebagai pembatas atas yang berbentuk daun, dengan isen-isen berupa titik-titik atau riningan berwarna putih. Warna putih nampak diterapkan sebagai latar pada bagian tengah yang berbentuk belah ketupat, yang di dalamnya dipenuhi dengan isen-isen berupa gringsing dengan titik berwarna putih pada bagian tengahnya. Apabila ragam hias yang diwujudkan melalui unsur kombinasi tersebut secara tekstual diurai maknanya, maka dapat dijabarkan sebagai berikut.

- Ragam hias garudha
Dalam mitologi Hindu ada angapan bahwa garudha merupakan burung matahari atau rajawali matahari. Di samping sebagai simbol matahari, garudha merupakan kendaraan dan lambang dari Dewa Wisnu (Soedarsono, 1997: 117-118). Ragam hias garudha diwujudkan dengan bentuk sawat dan lar, yaitu berwujud sayap, melambangkan sifat yang tabah. Garudha dijadikan simbol matahari sesuai perannya sebagai lambang dewa tertinggi Kahyangan dan alam semesta (Bronwen and Solyom, 1979: 69). Sebagai salah satu perlambang aspek kemahakuasaan Tuhan Yang Maha Esa, ia memiliki misi untuk membebaskan umat manusia dari belenggu perbudakan atau penjajahan (baik bersifat jasmaniah maupun bersifat rohaniah) yang menyesatkan. Ragam hias ini juga sebagai lambang kalepasan (kebebasan jiwa) dari seseorang yang telah meninggal dunia (Titib, 2003: 386-390).

- Ragam hias naga

Ragam hias naga seringkali dikaitkan dengan dunia bawah atau yang berunsur air. Berkebalikan dengan ragam hias burung yang melambangkan dunia atas. - Ragam hias pusaka

Pusaka mempunyai makna semacam daru atau wahyu, yaitu semacam cahaya gemerlapan atau sejenis planetplanet dan bintang-bintang gemerlapan di angkasa sebagai lambang kegembiraan dan ketenangan (Susanto, 1980: 235-236). Pusaka seringkali dihubungkan dengan kesaktian, kekuasaan, dan kemakmuran (Suyanto, 2002: 36), juga menjadi simbol kepandaian, keuletan, dan ketangkasan dalam menghadapi tantangan hidup. Ragam hias pusaka dimaknai agar hendaknya manusia senantiasa memiliki 
pikiran tajam, belajar olah rasa, dan dapat menghadapi berbagai situasi dan kondisi apapun (Herusatoto, 2003: 81).

- Ragam hias lidah api

$$
\text { Ragam hias lidah api }
$$

melambangkan sebuah kekuatan. Kekuatan ini apabila terkendali akan menjadi sebuah watak pemberani, berjiwa pahlawan, sifat bijaksana, dan berbudi luhur. Akan tetapi apabila kekuatan ini tidak terkendali, maka akan menjadi sifat angkara murka (Susanto, 1980: 271). Ragam hias lidah api juga untuk menggambarkan dan melambangkan orang-orang dengan kemampuan yang luar biasa (sakti), seperti seorang raja yang dapat mengeluarkan sebuah kekuatan dalam bentuk nyala api (Marmodiredjo, 1858: 13), sehingga ragam hias lidah api ini juga dipahami sebagai lambang kesaktian (van der Hoop, 1949: 298).

- Ragam hias burung

Ragam hias burung merupakan perlambang dunia atas (udara/angin) dan melambangkan perwatakan yang luhur. Sebagai lambang surga dan kehidupan dewa-dewa di 'atas' (Anonim, 1985: 10), ragam hias ini juga menggambarkan roh orang-orang yang telah meninggal (van der Hoop, 1949: 166). Burung merupakan lambang martabat atau harga diri, yaitu sebuah kesadaran diri sebagai cerminan Tuhan, cerminan kebenaran dan kebaikan, atau keserupaan hakekat dari Tuhan (Sastroamidjojo, 1958: 134), juga seringkali dihubungkan dengan perlambang perdamaian dan kemakmuran (Fraser-Lu, 1985: 46).

- Ragam hias kayon atau gunungan

Ragam hias kayon atau gunungan juga dikenal sebagai ragam hias meru melambangkan unsur yang berhubungan dengan bumi atau daratan (tanah), sebagai salah satu dari empat unsur hidup (bumi, api, air, dan angin). Meru menggambarkan proses hidup tumbuh di atas tanah. Proses ini yang disebut dengan semi, dan hal-hal yang menggambarkan semi disebut semèn (Susanto, 1980: 261). Meru merupakan penggambaran gunung yang berkedudukan sebagai sebuah tempat yang penting dalam mitologi Hindu sebagai simbol kekuatan (lons, 1967: 109). Makna dari ragam hias meru merupakan manifestasi yang berkaitan dengan kepercayaan manusia terhadap Tuhan Yang Maha Esa. Manusia sebagai bagian dari alam semesta ini hendaknya senantiasa menjaga keseimbangan dan keselarasan antara mikrokosmos dan makrokosmos. Hal ini juga berkaitan dengan hakekat manusia yang berasal dari Tuhan dan akhirnya ia akan kembali lagi kepada-Nya.

- Ragam hias dhampar

Ragam hias dhampar dalam konteks ragam hias semèn melambangkan suatu kekuasaan yang adil dan dan pengayom rakyat. Dhampar adalah tempat duduk seorang raja sebagai seseorang yang memiliki makna atau wahyu sebagai penjelmaan dewa. Dengan demikian seringkali seorang raja dianggap sebagai manusia yang memiliki kelebihan-kelebihan atau kesaktian jika dibandingkan dengan manusia biasa (Susanto, 1980: 235).

- Ragam hias pohon hayat

Pohon hayat merupakan representasi dari pohon kehidupan sebagai pilar kehidupan alam semesta dari adanya musim semi (masa pertumbuhan). la melambangkan jumlah kesatuan dan keesaan Tuhan yang menciptakan alam semesta, sehingga seringkali dianggap 
sebagai pohon keramat (Banuharli, 2003: 47). Disebut kalpataru, merupakan lambang dari alam seisinya sebagai sumber kehidupan bagi manusia dan makhluk lainnya (Herusatoto, 2003: 109). Dipahami sebagai pohon hidup yang menjadi sumber kebahagiaan, sumber keagungan, sumber asal mula kejadian, sumber asal dan tujuan hidup di atas segalanya (Haryanto, 1995: 31). Dunia tengah (madya) juga dilambangkan dengan unsur ragam hias pohon hayat yang mengisyaratkan makna akan adanya kehidupan yang subur dan makmur, juga melambangkan adanya kelanjutan abadi di alam yang lain (Kartiwa, 1987: 7).

\section{PENUTUP}

Ragam hias semèn pada batik klasik gaya Yogyakarta dipengaruhi oleh budaya Hindu-Jawa dan Islam. Pengaruh dari agama Islam ini kemudian nampak melahirkan beberapa ragam hias dalam wujud stilisasi. Setelah diurai dan dijabarkan, maka pada ragam hias semèn rama ditemukan dua buah ragam hias yang memiliki unsur kombinasi di dalamnya, yaitu ragam hias garudha yang dikombinasikan dengan ragam hias naga dan ragam hias pusaka yang dikombinasikan dengan ragam hias lidah api. Pada ragam hias semèn sida mukti ditemukan sebuah ragam hias yang memiliki unsur kombinasi, yaitu ragam hias garudha yang dikombinasikan dengan ragam hias burung. Pada ragam hias semèn sida luhur ditemukan dua buah ragam hias yang memiliki unsur kombinasi, yaitu ragam hias garudha yang dikombinasikan dengan ragam hias gunungan atau kayon dan dhampar serta ragam hias dhampar yang dikombinasikan dengan ragam hias tumbuhan atau pohon hayat.

Artikel ini masih menyisakan sebuah pertanyaan yang perlu dikaji secara lebih mendalam, yaitu apakah ragam hias yang diwujudkan dengan unsur-unsur kombinasi memiliki kesamaan makna ataukah berbeda dengan unsur ragam hias yang diwujudkan secara tunggal atau non kombinasi. Mudah-mudahan pertanyaan tersebut ke depan dapat ditelaah secara lebih lanjut ke dalam sebuah penelitian tersendiri.

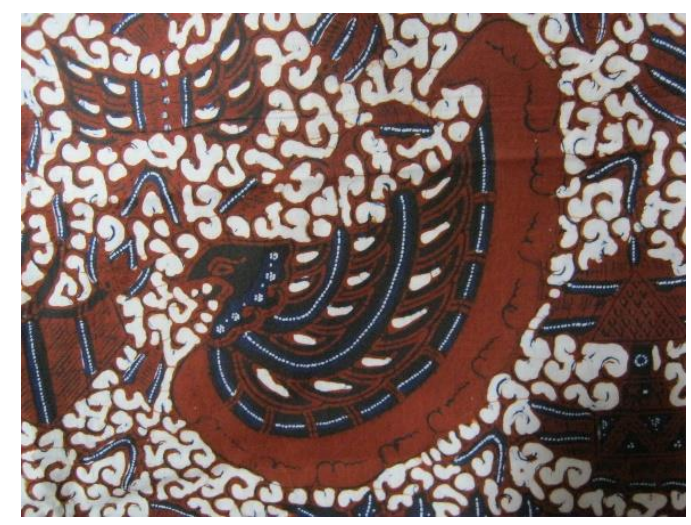

Gambar 1. Ragam hias garudha (semèn rama)

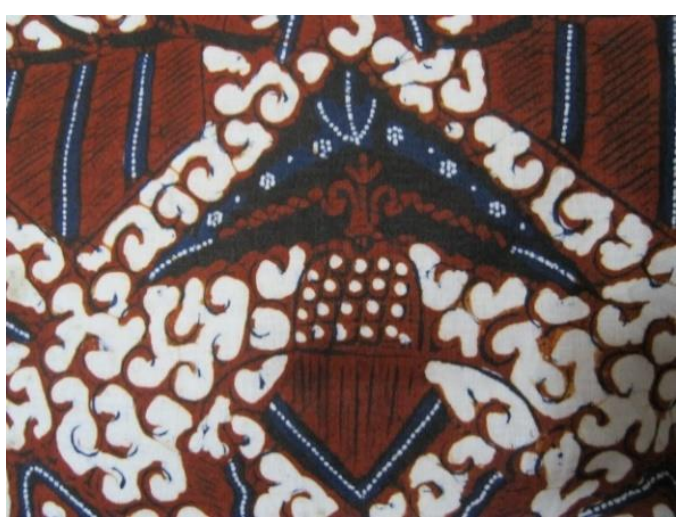

Gambar 2. Ragam hias pusaka (semèn rama) 


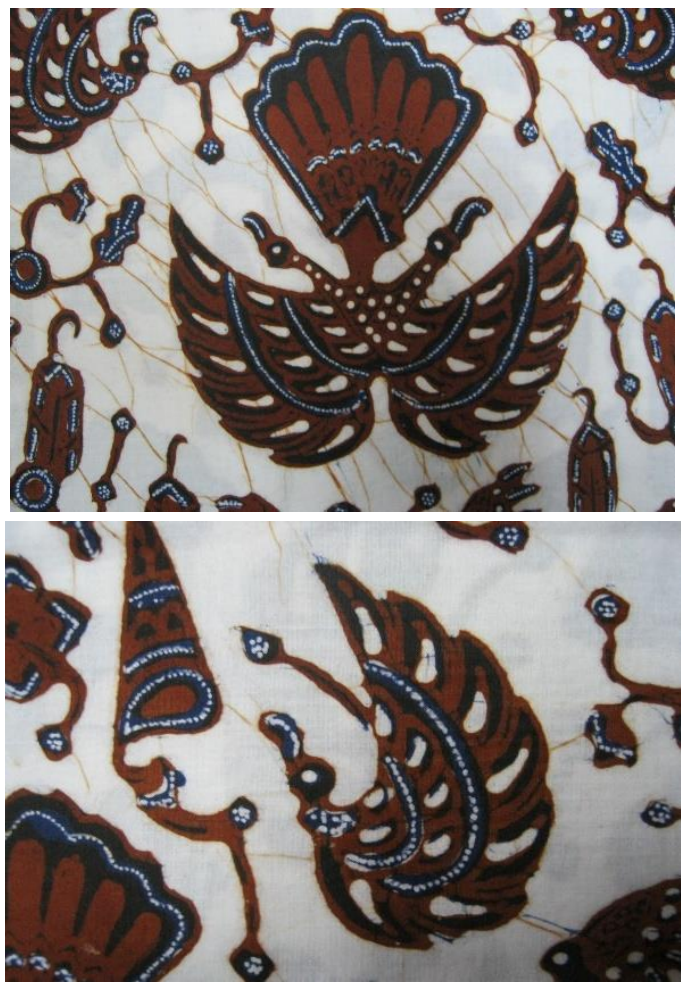

Gambar 3.Ragam hias garudha (semèn sida mukti)

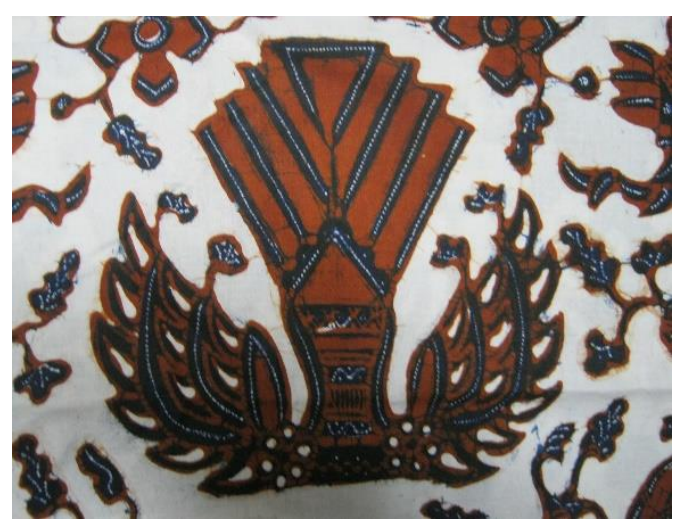

Gambar 4.Ragam hias garudha (semèn sida luhur)

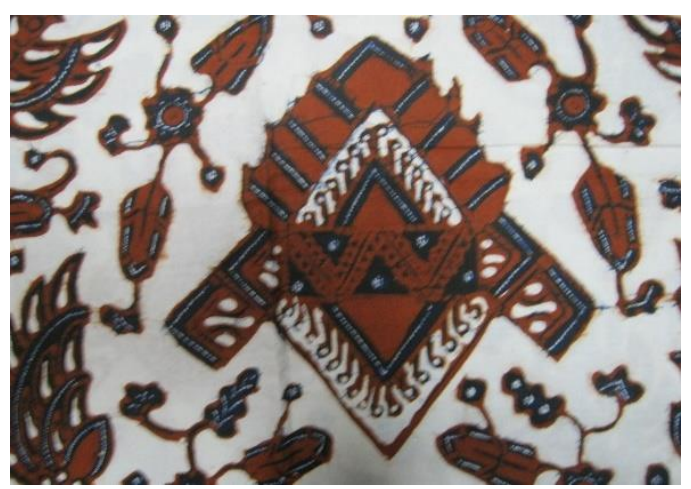

Gambar 5. Ragam hias dhampar (semèn sida luhur)

\section{DAFTAR PUSTAKA}

Amin, H.M. Darori, 2002, Islam \& Kebudayaan Jawa, Yogyakarta: Gama Media.

Majalah Femina, 23 Juli, 1985, Simbolisme dalam Corak dan Warna Batik. No.28/XIII-Jakarta.

Bronwen and Solyom, Garret, 1979, "Notes and Observation on Textile," dalam Joseph Fischer, ed., Threads of Tradition, California: University of California.

Dofa, Anesia Aryunda, Batik Indonesia, Jakarta: PT. Golden Terayon Press.

Fraser-Lu, Sylvia, 1985, Indonesian Batik: Processes, Patterns, and Places, Singapore: Oxford University Press.

Haryanto, S., 1995, Bayang-bayang Adhiluhung: Filsafat, Simbolis, dan Mistik dalam Wayang, Semarang: Dahara Prize.

Herusatoto, Budiono, 2003, Simbolisme dalam Budaya Jawa, Yogyakarta: Hanindita Graha Widya,

Ions, Veronica, 1967, Indian Mythology, London: Paul Hamlyn.

Kartiwa, Suwati, 1987, Tenun Ikat: Indonesia Ikats, Jakarta: Djambatan.

Kawindrasusanto, Kuswadji, "Mengenal Seni Batik di Yogyakarta,"dalam Soedarso Sp. Ed., 1998, Seni Lukis Batik Indonesia: Batik Klasik Sampai Kontemporer, Yogyakarta: Taman Budaya Propinsi Daerah Istimewa Yogyakarta \& IKIP Negeri Yogyakarta. 
Marmodiredjo, Tasan, 1858, Sedjarah Seni Rupa Djawa-Hindu, Jogjakarta: t.p.

Riyanto, et al., 1997, Katalog Batik Indonesia, Yogyakarta: Balai Besar Penelitian dan Pengembangan Industri Kerajinan dan Batik Proyek Pengembangan dan Pelayanan Teknologi Industri Kerajinan dan Batik.

Sastroamidjojo, A. Seno, 1958, Nonton Pertunjukan Wayang Kulit, Yogyakarta: PT. Percetakan Republik Indonesia.

Sedyawati, Edi, 2002, "Pengaruh HinduBuddha dalam Seni Indonesia," dalam Hilda Soemantri, Indonesian Heritage: Seni Rupa, Jakarta: Buku Antar Bangsa.

Soedarsono, R.M., 1997, Wayang Wong: Drama Tari Ritual Kenegaraan di Keraton Yogyakarta, Yogyakarta: Gadjah Mada University Press.

Soerjanto, T.T., t.t., Galeri Batik Kuno Danar Hadi: Panduan dan Denah, Surakarta: t.p.

SP. Gustami, Studi Komparatif Gaya Seni Yogya-Solo, 2000, Yogyakarta: Yayasan Untuk Indonesia \& LP$|S|$.

Susanto, S.K. Sewan, 1980, Seni Kerajinan Batik Indonesia, Yogyakarta: Balai Penelitian Batik dan Kerajinan, Lembaga Penelitian dan Pendidikan Industri

Departemen

Perindustrian RI.

1984, Seni dan Teknologi

Kerajinan Batik, Jakarta: Departemen

Pendidikan dan Kebudayaan Direktorat Jenderal Pendidikan Dasar dan Menengah.
Suyanto, A.N., 2002, Makna Simbolis Motifmotif Batik Busana Pengantin Jawa. Laporan Penelitian tidak diterbitkan, Yogyakarta: Lembaga Penelitian Institut Seni Indonesia.

Titib, I Made, 2003, Teologi \& Simbolsimbol dalam Agama Hindu, Surabaya: Paramita.

van der Hoop, A.N.J. Th. a. Th., 1949, Indonesische Siermotiven: Ragam ragam Perhiasan ndonesia: Indonesian Ornamental Design, Bandung: Koninklijk Bataviaasch Genootschap van Kunsten en Wetenschappen.

Widodo, Suryo Tri, 2014, Visualisasi Ragam Hias Batik Klasik Semèn Gaya Yogyakarta, Laporan Penelitian Hibah Penelitian Disertasi Doktor tidak diterbitkan, Yogyakarta: Lembaga Penelitian Institut Seni Indonesia Yogyakarta.

Yudoseputro, Wiyoso, "Pengaruh Islam dalam Seni Indonesia," dalam Hilda Soemantri, Indonesian Heritage: Seni Rupa, Jakarta: Buku Antar Bangsa. 